\title{
EFFECTS OF DIFFERENT STIRRER-PIN FORMS ON THE JOINING QUALITY OBTAINED WITH FRICTION-STIR WELDING
}

\author{
VPLIV RAZLIČNIH OBLIK VRTILNIH KONIC NA KVALITETO \\ SPOJA PRI TORNEM VRTILNEM VARJENJU
}

\author{
Hudayim Basak ${ }^{1}$, Kadir Kaptan ${ }^{2}$ \\ ${ }^{1}$ Gazi University, Technology Faculty, Department of Industrial Design Engineering, Ankara, Turkey \\ ${ }^{2}$ Gazi University, Technical Education Faculty, Department of Mechanical Education, Ankara, Turkey \\ hbasak@gazi.edu.tr \\ Prejem rokopisa - received: 2014-04-02; sprejem za objavo - accepted for publication: 2014-10-15
}

doi:10.17222/mit.2014.062

\begin{abstract}
In this study, 20 different pins that could be employed in friction-stir welding were manufactured. These pins and the Al7075 T6 material were joined with the friction-stir-welding technique. Tensile tests, microstructure and microhardness measurements, scanning-electron-microscopy (SEM) and energy-dispersion-spectrometry (EDS) analyses were conducted on the components joint by friction-stir welding. Designs of the weld and the tip that achieve the best performance were determined.

Keywords: friction-stir welding, stirrer-pin forms

V tej študiji je bila napravljena primerjava 20 različnih konic, ki se uporabljajo pri tornem vrtilnem varjenju. Konice in Al7075 T6 material so bili spojeni s tornim vrtilnim varjenjem. Pri komponentah, spojenih z vrtilno tornim varjenjem, so bili izvršeni natezni preizkusi, pregledana mikrostruktura in izmerjena mikrotrdota. Uporabljena je bila vrstična elektronska mikroskopija (SEM) in energijsko disperzijska rentgenska spektroskopija (EDS). Določena je bila tudi oblika zvara in konice, kjer so bile dosežene najboljše lastnosti.

Ključne besede: torno vrtilno varjenje, oblika konic
\end{abstract}

\section{INTRODUCTION}

Friction-stir welding (FSW) is a welding method undergoing continuous development that was originally introduced in England (Cambridge) in 1991,1,2 and went through a major development in the 1990s. ${ }^{3,4}$ Newly developed materials generally require modern joining techniques. With the development of new alloys in the past twenty years, major advances were also made regarding the welding of these materials. Friction-stir welding (FSW) was successfully employed in the welding of aluminum alloys that are difficult to weld with the traditional melt-welding methods, especially those that are subjected to age hardening. ${ }^{5,6}$

The problems arising from joining aluminum and Al-alloys with the traditional melt-welding methods stimulated the researchers to develop new joining methods. When joining aluminum alloys (especially those subjected to age hardening) with the melt-welding methods, a high heat input may culminate in these materials leading to a high thermal expansion and crack formation in the welding seam due to wide solidification intervals. ${ }^{7}$ In addition, it is known that the high heat input in arc welding leads to the formation of low melting-point phases at the grain boundaries in the region under the effect of the heat in aluminum alloys and, therefore, cracks at the grain boundaries of the region during the solidification. Another problem encountered when joining aluminum alloys subjected to age hardening with the melt-welding methods is a reduction in the hardness and strength due to the solution of hardening precipitates in the welding seam and an excessive aging of the heateffected zone..$^{8-10}$ This situation results in mechanical disconformities in the welding zone. Due to these specific reasons, solid-state welding methods (diffusion, friction and friction-stir welding) provide huge advantages for the welding of these materials.

Friction-stir welding, which is a solid-state welding method, is an appropriate alternative welding method for joining the materials whose welding construction is difficult, due to its unique advantages like a brief welding duration, minimum surface preparation and ease of automation. ${ }^{11}$ With this method, no protective gas, additional welding metal or opening of the welding grooves on the components to be welded are necessary. The welding quality of the welded joints obtained with friction-stir welding does not show variation with respect to the type of material. ${ }^{10}$ Even though the method is suitable for several materials, its most significant area of application is the welding of aluminum and aluminum alloys. Aluminum alloys joined with this method exhibit decent mechanical properties. ${ }^{12}$ The FSW method can be comfortably applied in all positions. ${ }^{13,14}$ In the studies conducted for aluminum materials, it was found that appropriate joining can be performed for plate thicknesses between $1-75 \mathrm{~mm} \cdot{ }^{15}$

The tool-pin profile and welding parameters play major roles in achieving the quality of friction-stir weld- 
ing. Friction-stir-welding studies used different parameters and stirrer pins made for these studies. The effect of the tool-pin profile on mechanical properties was the subject of a few studies. ${ }^{16-18}$ The effect of the tool-pin profile on the bonding and mechanical properties was investigated together with certain parameters such as the rotational speed, ${ }^{16}$ welding speed ${ }^{19}$ shoulder diameter ${ }^{20,21}$ and axial force. ${ }^{22}$ Also, in recent years, some studies have been made on the optimization of the tool geometry using statistical analyses and finite-element methods..$^{23,24}$

\section{EXPERIMENTS AND MATERIAL}

The Al7075 material was chosen to be employed in this study. For the FSW method, this material was chosen due to its superior hardness, tensile strength, joining capability

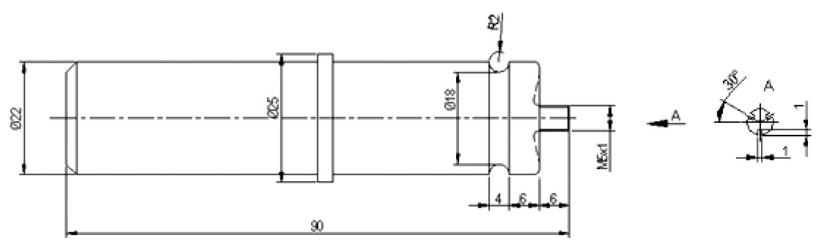

Figure 1: Drawing of a manufactured stirrer pin

Slika 1: Risba izdelane konice

and resistance properties. In addition, the Al7075 material is used in many industrial areas (especially in the space and aeronautical industry) thanks to its mechanical properties. Stirrer-pin profiles were formed by taking screw-thread types (metric (triangular), trapezoidal, circular, square and saw-shaped) into consideration. Along with that, in the case when no screw thread is cut, triangular, cylindrical, conical

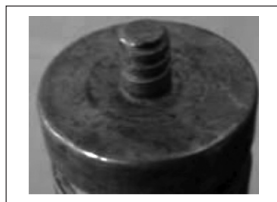

1.

Square screwed stirrer pin

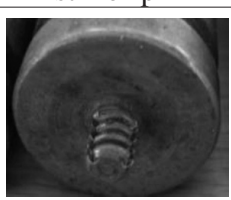

7.

3-groove circular screwed stirrer pin)

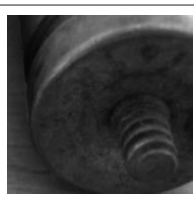

2.

Circular screwed stirrer pin

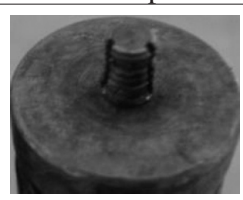

8.

9.

3-groove triangular 3 -groove trapezoidal 3 -groove saw-type (metric) screwed screwed stirrer pin stirrer pin

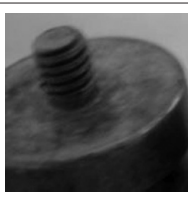

3.

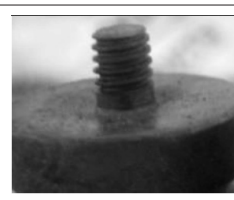

4. screwed stirrer pin

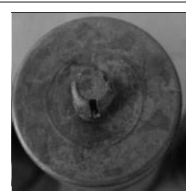

5.

Saw-type screwed stirrer pin

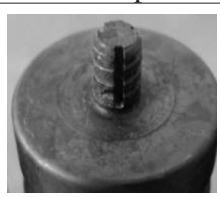

11.

4-groove square screwed stirrer pin

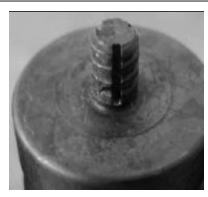

6.

3-groove square screwed stirrer pin

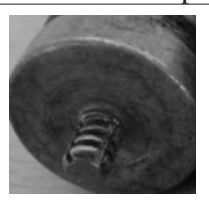

12.

4-groove circular screwed stirrer pin
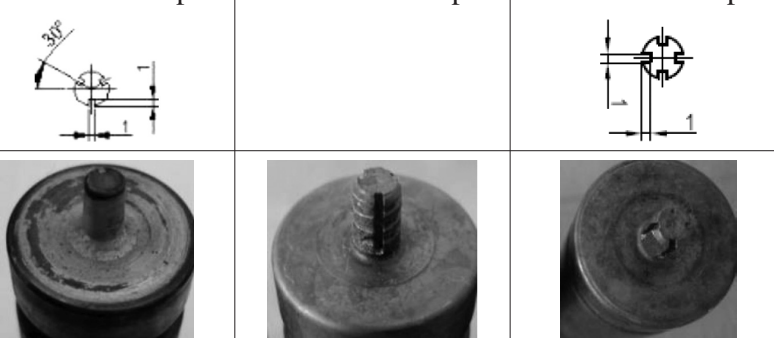

13. (metric) screwed
screwed stirrer pin stirrer pin

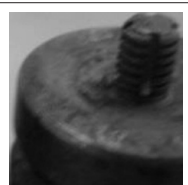

4.
15.

4-groove saw-type screwed stirrer pin

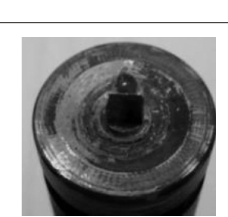

19.

Unscrewed triangular profiled stirrer pin (mis
18.

17.

16.

Unscrewed conical Unscrewed 3-groove Unscrewed 4-groove profiled stirrer pin circular profiled

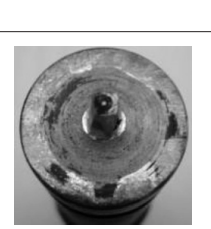

20.

Unscrewed square profiled stirrer pin

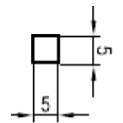

Figure 2: Manufactured stirrer pins

Slika 2: Izdelane vrste konic 
and square pin profiles were created in order to compare the joining qualities of the pin profiles. Stirrer pins were manufactured on the basis of the drawing given in Figure 1. The manufacturing principle for all the stirrer pins was taken into account in accordance with this drawing. As it is theoretically known, screw types are divided into two groups: connection and movement types. The triangular screw type is the most frequently used connection bolt. Since the profile gradient in triangular profile screws increases the frictional resistance $\left(\mu^{\prime}=\tan \rho^{\prime}=\mu /(\cos (\beta / 2))\right.$, the friction per unit area for triangular threads is at the highest level. As for the movement bolts, the friction per unit area is very low. ${ }^{25}$ For the profiles designed on the basis of this theoretical information, we can predict that, of all the pin designs, the highest joining-strength quality is achieved with the triangular screw. We can also state that low joining strengths are achieved with the movement-type screws (circular and square). The AISI/SAE 4340 (DIN 1.6582, EN 34CrNiMo6) material was selected as the stirrer-pin material and it was subjected to a heat treatment for a hardness of 50-52 HRC. The stirrer pins were made ready for use with the FSW method. The manufactured stirrer pins are presented in Figure 2.

\subsection{Friction-stir-welding method}

The friction-stir welding process is shown in Figure 3. The FSW method is a type of welding that was developed using the friction-stir-welding technique. This welding method consists of moving an immersed shoulder pin (probe) revolving at a high speed over two plates butted to each other at a particular speed. ${ }^{26}$ Even though aluminum alloys are usually difficult to weld, this method can be used for enhancing the welding performance. Researchers are focused on joining aluminum alloys. This welding method was applied on aluminum materials thinner than $1 \mathrm{~mm}$ and thicker than $35 \mathrm{~mm}$ and it was found that very good mechanical properties were achieved. ${ }^{27-31}$

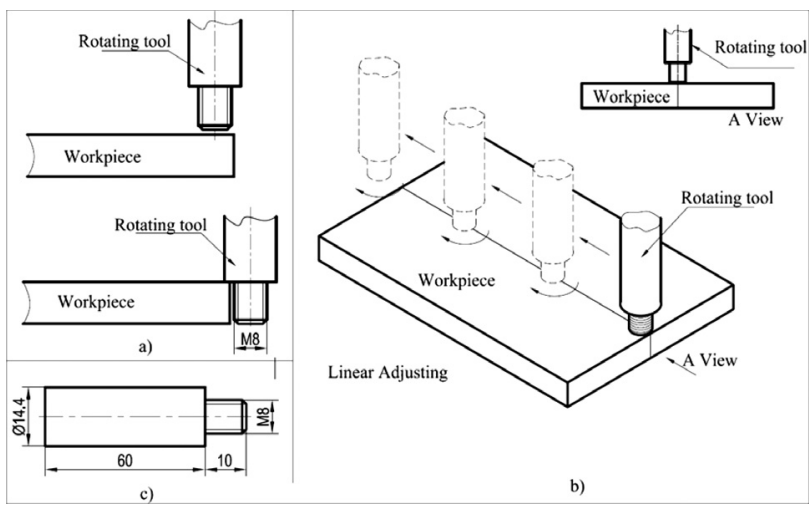

Figure 3: a) Tool approaching the workpiece, b) adjusting the tool before the welding, c) drawing of the tool ${ }^{30,31}$

Slika 3: a) Orodje se približuje obdelovancu, b) prilagoditev orodja pred varjenjem, c) risba orodja ${ }^{30,31}$
The parameters used in the tests are given in Table $\mathbf{1}$.

Table 1: Test parameters

Tabela 1: Parametri preizkusa

\begin{tabular}{|l|l|}
\hline \multicolumn{1}{|c|}{ Material } & \multicolumn{1}{c|}{$\begin{array}{c}\text { Aluminum alloy (Al7075 T6), } \\
\text { a }(80 \times 120) \mathrm{mm} \text { prismatic component }\end{array}$} \\
\hline Stirrer pins & $\begin{array}{l}20 \text { stirrer pins created on the basis of } \\
\text { screw types }\end{array}$ \\
\hline Feed rate & $28-40 \mathrm{~mm} / \mathrm{min}$ \\
\hline $\begin{array}{l}\text { Number of } \\
\text { revolutions }\end{array}$ & $710-1200 \mathrm{r} / \mathrm{min}$ \\
\hline $\begin{array}{l}\text { Bench used for } \\
\text { burnishing process }\end{array}$ & $\begin{array}{l}\text { Taksan 40T1500, a CNC milling bench } \\
\text { with a vertical processing center }\end{array}$ \\
\hline
\end{tabular}

During the construction stage of friction-stir welding, the values of the movement rate and rotational speed were determined separately for different stirrer pins. The reason for this is the fact that a rotational speed yielding very good results for one pin does not provide for an efficient joining for another pin. Therefore, the values that yield good welding results were determined in terms of increasing or decreasing the movement and rotational speeds. In this way, the welding operation was carried out (Figure 4).

The friction-stir welding was started with ungrooved stirrer pins and the welding was performed with square, circular, saw-type, trapezoidal and triangular screwed
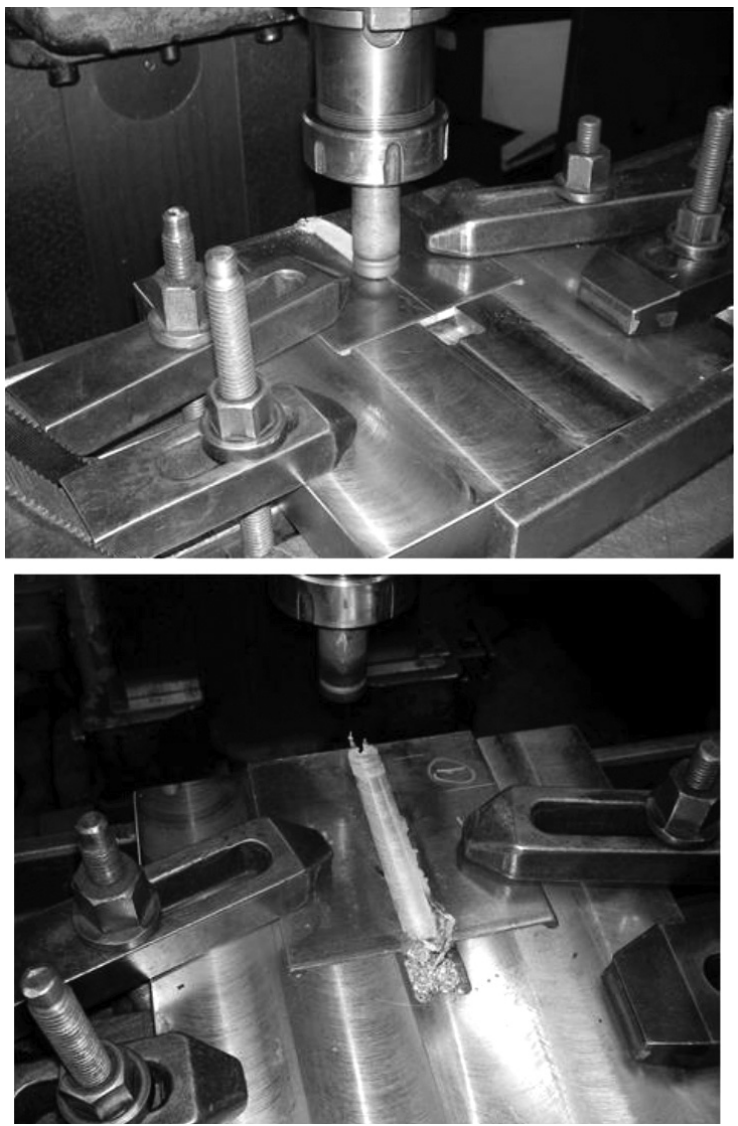

Figure 4: Performing the welding operation

Slika 4: Izvedba varjenja 
stirrer pins. In the welding operations involving the circular, trapezoidal and triangular screwed 3-groove pins, the components were welded at a rotational speed of $1200 \mathrm{r} / \mathrm{min}$ and a movement rate of $28 \mathrm{~mm} / \mathrm{min}$. In the cases of the 4-groove pins, fractures occurred in the triangular and saw-type screwed pins. A good joint was achieved at the rotational rate of $1200 \mathrm{r} / \mathrm{min}$ and the movement rate of $28 \mathrm{~mm} / \mathrm{min}$.

Lastly, the joining operation was conducted with untapped stirrer pins. The joining could not be achieved with these pins when carried out on the basis of standard workpiece values. In order to ensure the joining, the movement rate was reduced to $28 \mathrm{~mm} / \mathrm{min}$ and the rotation was increased to $1200 \mathrm{r} / \mathrm{min}$ according to our previous experiences and the joint was achieved in this manner. Afterwards, the process was finalized by performing joining operations with the 4-groove stirrer pins.

Since the triangular and saw-type threaded stirrer pins fractured at the selected standard rotational speed and movement rate, the stirrer-pin rotational speed was reduced to $710 \mathrm{r} / \mathrm{min}$ and the movement rate to 28 $\mathrm{mm} / \mathrm{min}$ and the joining was performed in this manner; lastly, the untapped stirrer pins were used for the joining operation. When the joining operation with these pins was conducted at the standard workpiece values, the joining did not take place. In order to ensure the joining, the movement rate was $28 \mathrm{~mm} / \mathrm{min}$ and the rotational speed was $1200 \mathrm{r} / \mathrm{min}^{32}$

\subsection{Tensile test}

For the entire FSW using different stirrer pins, three tensile-test samples were extracted from the welding samples joined with the FSW method. The samples were cut to the desired dimensions with the erosion machine and prepared for testing. The tensile-test samples were prepared according to standards TSE 138 (EN 10002-1). ${ }^{33}$ They were milled in a ZWICK tensile-testing device. During the test, the pulling speed was determined as $5 \mathrm{~mm} / \mathrm{min}$ and the frontload as $10 \mathrm{~N}$.

\subsection{Microstructure, scanning electron microscopy (SEM) and energy dispersion spectrometry (EDS)}

For the purpose of conducting a microstructural analysis, the welding samples joined with the screwed stirrer pins that display the highest and the lowest tensile strengths (triangular and circular screwed pins: samples $2,4,7,8,13)$ were selected. The samples were prepared with the standard metallographic sample-preparation method. At the end of this procedure, the samples were seared with a macro-searing machine.

A Prior light microscope was employed for scanning the microstructures and its images were transferred into a computer environment. In order to obtain the profiles of the microhardness distributions from the welded regions towards the main metal in the samples, loads of $100 \mathrm{~g}$ were applied on the samples with adjusted micro- structures, and their Vickers $\left(\mathrm{HV}_{0.1}\right)$ microhardness levels were measured with a Shimadzu microhardness device. The measurements were repeated at least three times, within certain intervals, and the graphs were obtained after taking the arithmetic averages and standard deviations. In addition, in order to determine the coating status of the stirrer-pin samples according to the pin geometry, a scanning electron microscope was employed. For this purpose, a Jeol 6060 LV SEM device was used. To prove that the coated material was welded, an EDS analysis was conducted using the IXRF (X-ray fluorescence) system.

\section{RESULTS AND DISCUSSION}

\subsection{Tensile-rest results and discussion}

Duplicates of the tensile-test samples prepared according to the standards were created. After this stage, the sample components were ready for the tensile test. Significant variations in the tensile-stress values of the used stirrer pins depending on their geometries were observed. The samples were usually ruptured from the welded zone to the main metal. The rupture points of samples 2, 4 and 13 are shown in Figure 5.

The welded connections created with the FSW operations using the screwed pins exhibit higher tensile strengths compared to those of the unscrewed pins.

The obtained tensile values are displayed as a graph in Figure 6. In this figure, stirrer pin " 0 " indicates the unwelded Al7075 material.

The samples formed with the screwed stirrer pins exhibited tensile-strength values close to that of the main component. The highest tensile strength was achieved by the sample component formed with the triangular (metric) screwed stirrer pin. The lowest tensile strength was exhibited by the unscrewed conical profiled stirrer pin. Among the sample components made with the unscrewed stirrer pins, the highest tensile strength was achieved with the square profile stirrer pin. The tensile strengths of the samples acquired with the unthreaded

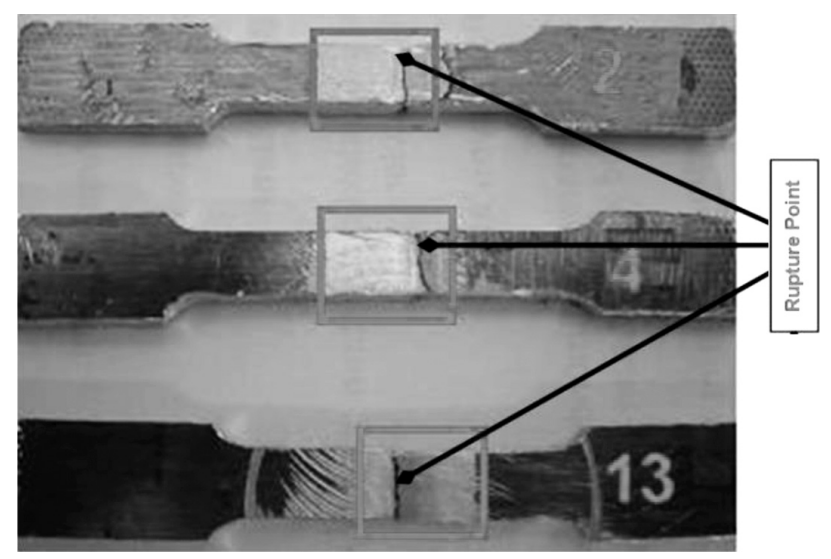

Figure 5: Rupture points on the samples used in the tensile test Slika 5: Mesto porušitve pri nateznem preizkusu vzorcev 


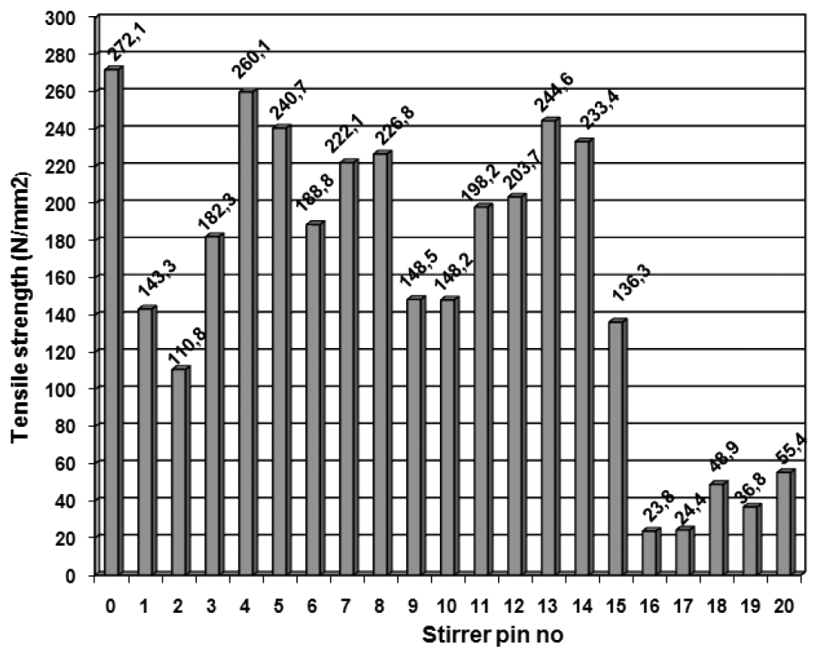

Figure 6: Tensile-test values of the welding samples created with FSW

Slika 6: Vrednosti, dobljene pri nateznem preizkusu vzorcev, zvarjenih s FSW

stirrer pins were well below the desired level. Therefore, the unthreaded pins were not used in the other analysis. The lowest tensile strength among the sample components made with the screwed stirrer pins was achieved with the circular screwed stirrer pin. On average, the lowest tensile strength among the sample components made with both the grooved and ungrooved screwed
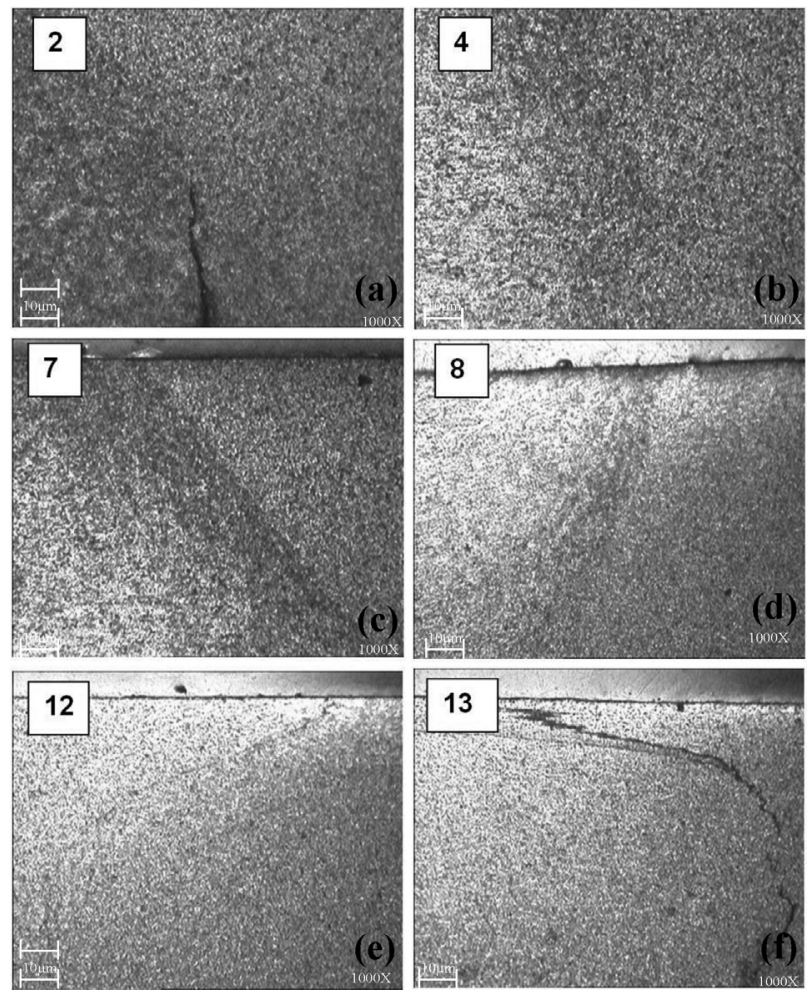

Figure 7: Microstructure images of samples joined with stirrer pins nos. 2, 4, 7, 8, 12 and 13

Slika 7: Posnetki mikrostrukture vzorcev, spojenih z vrtilno konico št. 2, 4, 7, 8, 12 in 13 stirrer pins was achieved with the square screwed stirrer pin. In general, better tensile strengths were achieved when grooves in the screwed stirrer pins were opened. Only with the triangular screw does the ungrooved screwed stirrer pin provide an exception.

In order for an FSW operation to be effective, the surface of the stirrer pin needs to be large. For this reason, it is believed that the parameter of the surface area, which depends on the stirrer pin's geometry, directly affects the FSW operation. If the surface area increases, the emerging quantity of heat is higher as friction is more dominant. Thus, it can be stated that a smoother stir can be obtained when joining two components. However, for some samples of this study, possibly due to the stirring geometry, the stir at the welding root was not homogeneous. In such cases, a microstructurecharacterization study was also performed.

\subsection{Microstructure and characterization of the welding interface}

The interface microstructures of the samples used in the FSW process are shown in Figures 7a to 7f. In sample 2 (the circular screwed stirrer pin), microfractures were found at the root of the weld. These fractures probably caused the mixture not to be effective. Hence, the tensile strengths of these samples turned out to be low (Figure 7a). It is seen that the FSW operations involving samples 4, 7 and 8 (triangular (metric) screwed stirrer pin, 3-groove circular screwed stirrer pin and 3 -groove triangular (metric) screwed stirrer pin, respectively) were more successful. No problems such as disintegration or cracking between the weld and the main metal were observed (Figures $\mathbf{7 b}$ to $\mathbf{7 d}$ ). However, the formation of thin cracks seen on sample 13 (the 4-groove triangular (metric) screwed stirrer pin) is thought to be resulting from the thermal expansion (Figure 7f).

The samples prepared for the microstructural analysis were used for microhardness measurements. During these measurements, a $100 \mathrm{~g}(0.1 \mathrm{HV})$ pressure in terms of $\mathrm{HV}$ (Vickers) was applied for $5 \mathrm{~s}$. The hardness was measured at 3 different zones, starting at the weld zone,

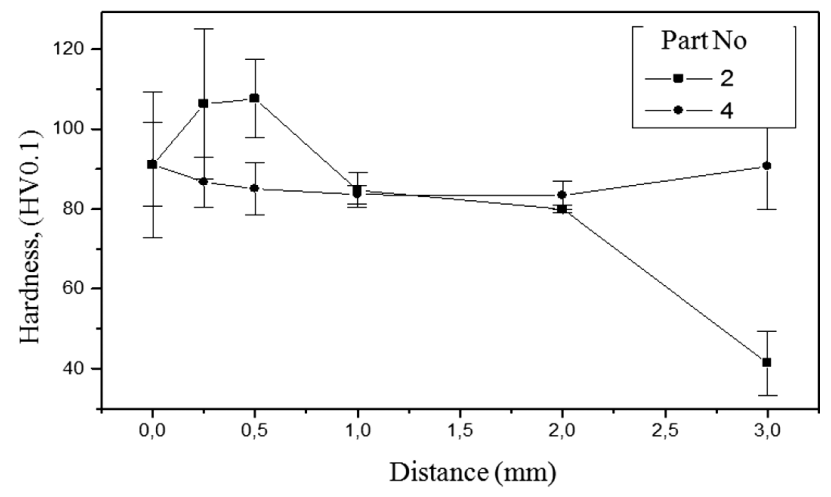

Figure 8: Comparison of microhardness values for samples nos. 2 and 4

Slika 8: Primerjava vrednosti mikrotrdote vzorcev št. 2 in 4 


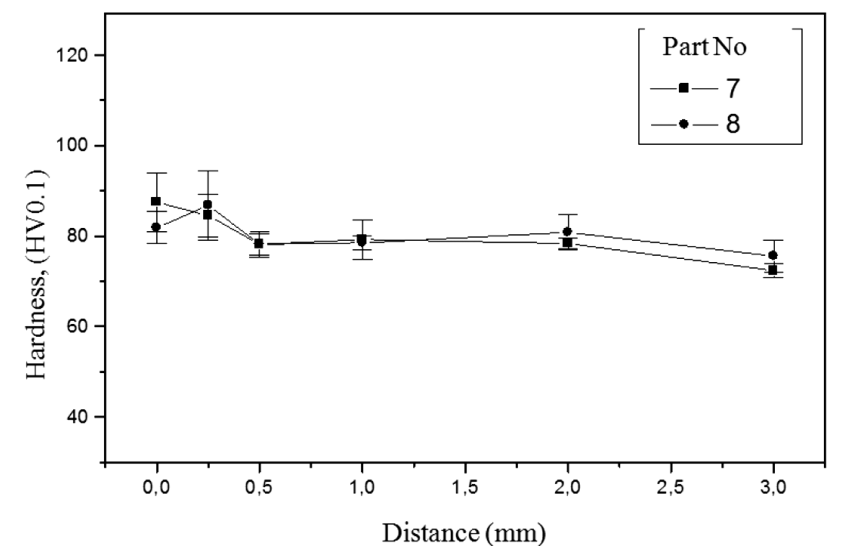

Figure 9: Comparison of microhardness values for samples nos. 7 and 8

Slika 9: Primerjava vrednosti mikrotrdote vzorcev št. 7 in 8

at distances of $(0.25,0.5,1,2$ and 3$) \mathrm{mm}$. The determined microhardness average and the standard deviation were calculated. Graphs of the determined values were prepared for comparison.

In Figures $\mathbf{8}$ to $\mathbf{1 0}$ the graphs displaying the microstructure profiles of the samples subjected to the FSW operation, measured at specific intervals from the weld zone towards the main metal are given. These graphs provide significant information about whether the FSW operations were conducted correctly or not. In Figure 9, the hardness profiles belonging to samples 7 and 8 relate to the FSW operation conducted with the 3-groove circular screwed stirrer pin and 3-groove triangular (metric) screwed stirrer pin. It is observed that the hardness profiles of the samples exhibit similar tendencies after both situations. No significant variation is observed in the hardness tendencies from the weld zone towards the main metal. This situation explicitly demonstrates that the other mechanical properties of these samples may also be superior. However, it is seen that the hardness relatively increased in sample 8, made with the 3 -groove triangular (metric) screwed stirrer pin, at about a distance of $0.25 \mathrm{~mm}$ from the weld zone. The potential reason behind this situation may be the thinning of crystallized grains as a consequence of excessive heat and sudden cooling taking place at this region. As it is known, a deformation of crystal grains of a material whose recrystallization mechanism was deformed, takes place as a result of the formation of subgrain boundaries at the end of dynamic recovery that occurs due to a polygonization of dislocations when the material's temperature reaches between $1 / 3-2 / 3$ of its melting temperature. Probably, this mechanism took place in sample 8 . At the same time, the tensile values of samples 7 and 8 can be explained with their hardness profiles and they turn out to be similar. In general, it is observed that the average hardness tendencies of these samples are relatively lower compared to the other samples. This may be considered to be leading to the relatively lower tensile strengths of these samples. The fact that the average hardness of these samples turned out to be low can be attributed to a larger temperature increase in these samples during the FSW operation. It can be shown that the higher friction provided by the stirrer pins used for these samples causes the temperature of the samples to become higher.

Figure 8 shows the hardness profiles for samples 2 and 4 after the FSW operation was conducted with the circular screwed stirrer pin and triangular (metric) screwed stirrer pin, respectively. It was observed that the distribution of the hardness for sample 4, the material with which the triangular (metric) screwed stirrer pin was used and which yielded the best result in the study, is more homogenous compared to all the other samples. This demonstrates that both the weld zone and the main metal were more modified in terms of the microstructure and chemical composition. This situation can also be seen clearly in Figure 7b. When the hardness profile for sample 2, whose FSW operation was done with the circular screwed stirrer pin, is examined, it is deduced from the increasing hardness that in this sample, deformation hardening might have occurred in the region near the joining area (at the $0-0.5 \mathrm{~mm}$ interval). However, extreme deformation hardening may lead to microfractures like the ones that occurred in this sample due to an excessively increased density of dislocations. These microfractures, in turn, led to the sample's low tensile strength. It is likely that the decreasing effectiveness of the FSW was due to inadequate heat. Along with the inadequate level of the heat, an excessive plastic deformation might have lead to deformation hardening.

In Figure 10, the hardness profiles for samples 12 and 13, whose FSW operations were conducted with the 4-groove circular screwed stirrer pin and 4-groove triangular (metric) screwed stirrer pin, respectively, are demonstrated. Significant drops and rises in sample 13, in the regions near the joining area, stand out, while the hardness profile of sample 12 is smoother compared to sample 13. A possible reason behind this is thought to be the capillary fractures arising from the thermal expansion as seen from Figure 7f as well. For welded joints, this is

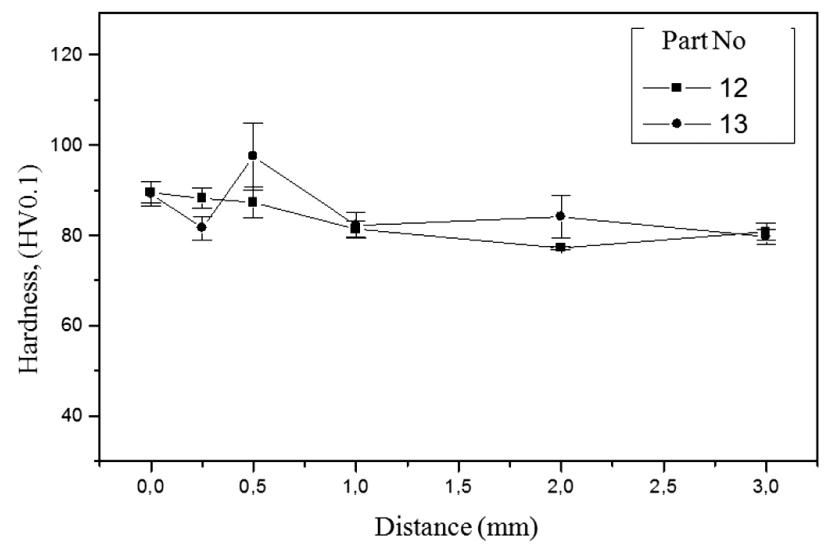

Figure 10: Comparison of microhardness values for samples nos. 12 and 13

Slika 10: Primerjava vrednosti mikrotrdote vzorcev št. 12 in 13 

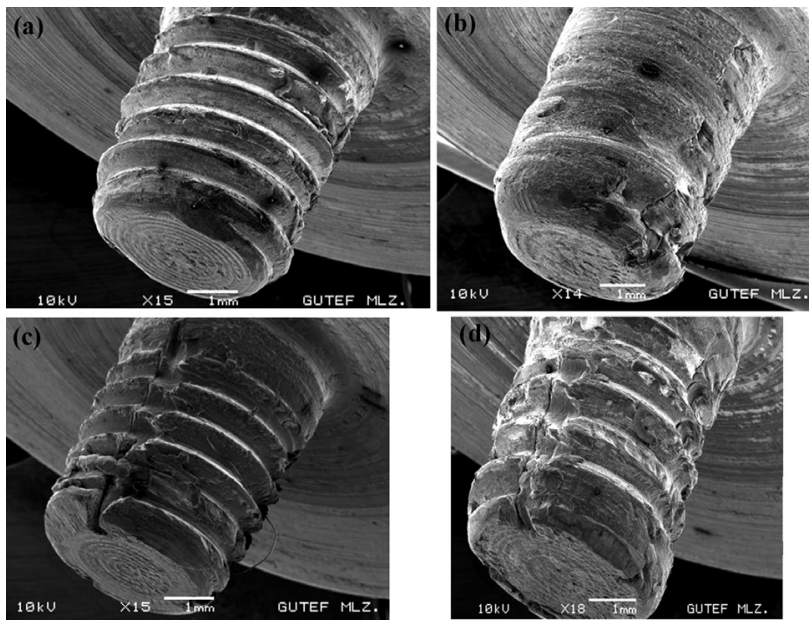

Figure 11: SEM images of stirrer pin: a) no. 4 (triangular screwed), b) 2 (circular screwed), c) 8 (3-groove triangular screwed) and d) 13 (4-groove triangular screwed)

Slika 11: SEM-posnetki vrtilnih konic: a) št. 4 (trikotni vijak), b) 2 (krožni navoj), c) 8 (trikotni vijak s tremi zarezami) in d) 13 (trikotni vijak s štirimi zarezami)

perceived to be a critical problem. However, if no such problem occurred in this sample, we could expect its hardness profile to be higher and smoother and, correspondingly, we could expect it to exhibit the highest tensile strength.

In order to see the changes in the physical structures of the stirrer pins after a welding operation, SEM images of some stirrer pins (triangular and circular screwed) were taken. The stirrer-pin images taken with SEM are given in Figure 11.

When the SEM images were analyzed, as seen at the first sight, a higher amount of the joining material was found to be covering the circular screwed stirrer pin compared to the triangular screwed stirrer pin. It was also observed that the circular screwed stirrer pin demonstrated the lowest strength among the screwed types during the tensile test and the highest joining strength

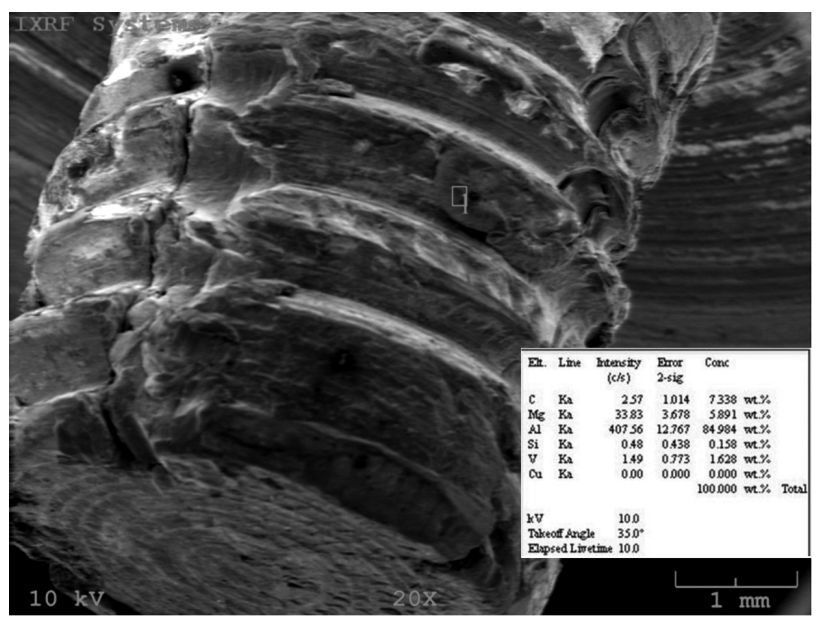

Figure 12: Stirrer pin on which EDS analysis was conducted Slika 12: Vrtilna konica z označenim mestom EDS-analize was obtained with the triangular screwed stirrer pin. On the basis of this observation, we can state that one reason why the joining performed with the circular screwed stirrer pin failed to display an adequate strength is the fact that a portion of the material was being deposited on the stirrer pin. In addition, it can be asserted that the grooves employed on the stirrer pins yield higher joining strengths than the ungrooved stirrer pins.

\subsection{EDS analysis of a stirrer pin}

For the purpose of making a partial estimation of the stirrer-pin lifetime, an EDS analysis of a stirrer pin was carried out (Figure 12). The EDS analysis was conducted in the marked zone on the stirrer pin and the materials found in it were determined.

After the analysis, no fragment was found to be broken from the stirrer pin's material. According to this result, we can assume that the stirrer pin can have a long lifetime. Also, we can presume that since the Al-alloy that collects over the stirrer-pin cavities and grooves due to the heat at each joining, a decrease in the performance of the stirrer pin will not take place.

\section{DISCUSSION}

The internal structure formed at the weld zone after the friction-stir welding consists of three different regions: the recrystallized region (RCR), the thermomechanically affected region (TAR) and the region under the influence of heat.

It was observed that the hardness increased in the weld zone of sample 2 (the circular screwed stirrer pin) and the hardness distribution from the weld zone towards the main metal decreased. However, there was no noteworthy variation in the hardness distribution between the weld zone and the main metal in sample 4 (the triangular screwed stirrer pin). Homogenous distributions of the microstructure and the hardness are essential for achieving the superior mechanical properties expected from the welded joints. On the other hand, the yield and tensile strength are proportional to the hardness. It is believed that even though the hardness level at the weld zone for sample 4 turned out to be lower than that of sample 2, the fact that its microstructure and hardness distributions are more homogenous leads to an increase in the sample's tensile strength. The microfractures seen at the welding root of sample 2 indicate that an effective stir did not take place and it is thought that this caused the tensile strength to be low.

Even though the hardness values for samples 7 and 8 were relatively a bit higher at the weld zones than at the main metal, it can be stated that they exhibited homogenous hardness distributions. Moreover, the hardness levels of both samples are similar in all the regions. Therefore, it is understood that both pins yield results similar to these properties. 
Even though the hardness distribution in sample 13 (the triangular screw stirrer pin) was expected to be homogenous, or just slightly higher at the midpoint of the weld zone, it was found to be higher in the region close to the main metal. The probable reason for this is an excessive increase in the temperature in the unmelted region close to the main metal because the friction stirring of the pin with this geometry is more dominant and, along with that, the grain structure becomes finer due to the influence of fast cooling. As for the hardness distribution in sample 12 (the circular screw stirrer pin) it is much more homogenous.

In general, it was observed that an increase in the hardness in the weld zones or regions close to the joining areas of the analyzed and discussed samples leads to an increase in their tensile strengths.

It was observed that the tensile values for the samples whose microstructures and microhardnesses demonstrate homogenous distributions are similar to those of the main metal. It was seen that the size and shape of the regions formed as a result of joining depend on the geometry of the stirrer pin. Hence, it can be concluded that the geometry of the stirrer pin has a significant effect on the mechanical behavior.

\section{CONCLUSIONS}

In this study, joining operations were carried out by employing the friction-stir welding technique. On the basis of the samples joined in this way, the stirrer pin providing the best performance was determined with tensile tests, microstructure characterizations, SEM and EDS.

As a result of the conducted studies, the results given below were obtained:

- It was observed that the welding seam made with the FSW is smoother than the seams obtained with the other methods.

- Among the stirrer pins, the best performance and highest joining strength were achieved with the triangular thread. It is suggested that this type is preferred in stirrer-pin designs.

- Neither the joining surface nor the tensile strength turned out to be at the desired level in the welds performed with the unscrewed stirrer pins.

- Among the joints made with the screwed stirrer pins, the poorest results were obtained with the circular threaded stirrer pins.

- As we had theoretically predicted, the lowest strengths were achieved with the conductive screws.

- Using the FSW method, a tensile-strength value close to the one of the main metal can be achieved.

- In the stirrer-pin designs, screwed types should be preferred as they facilitate the flow of the welding seam.

- The pins with large friction surfaces facilitate more homogenous and better joints.
- An increase in the hardness in the regions of the weld zone or close to the joining area increases the tensile-strength values.

- A larger friction surface of a stirrer pin increases the tensile strength of the welded joint.

\section{REFERENCES}

${ }^{1}$ G. Cam, Friction Stir Welding and Applications, $9^{\text {th }}$ Materials Symposium Proceedings, Pamukkale University, Denizli, 2002, 450-458

${ }^{2}$ M. W. Mahoney, C. G. Rhodes, J. G. Flintoff, W. H. Bingel, R. A. Spurling, Properties of friction-stir-welded 7075 T651 aluminum, Metallurgical and Materials Transactions A, 29 (1998) 7, 1955-1964, doi:10.1007/s11661-998-0021-5

${ }^{3}$ D. P. Field, T. W. Nelson, Y. Hovanski, K. V. Jata, Heterogeneity of crystallographic texture in friction stir welds of aluminum, Metallurgical and Materials Transactions A, 32 (2001) 11, 2869-2877, doi:10.1007/s11661-001-1037-2

${ }^{4}$ T. U. Seidel, A. P. Reynolds, Visualization of the material flow in AA2195 friction-stir welds using a marker insert technique, Metallurgical and Materials Transactions A, 32 (2001) 11, 2879-2884, doi:10.1007/s11661-001-1038-1

${ }^{5}$ W. M. Thomas, E. D. Nicholas, J. C. Needham, M. G. Murch, P. Templesmith, C. J. Dawes, Improvements to Friction Welding, GB Patent Application No.9125978.8, 1991

${ }^{6}$ C. Dawes, W. Thomas, Friction Stir Joining of Aluminium Alloys, TWI Bulletin, 6 (1995), 124

${ }^{7}$ G. Çam, Improved New welding Technology for Al-Alloys, Engineers and Machinery, 46 (2005), 30-39

${ }^{8}$ G. Çam, Developments in Friction Stir Welding, Part 1, Machine Technology, 80 (2004), 44-49

${ }^{9}$ G. Çam, Developments in Friction Stir Welding, Part 2, Machine Technology, 81 (2004), 100-104

${ }^{10}$ M. K. Külekçi, A. Şık, Sürtünme Karıştırma Kaynağı İle Alüminyum Alaşımı Levhaların Birleştirilmesi Ve Elde Edilen Kaynaklı Bağlantıların Mekanik Özellikleri, Süleyman Demirel Üniversitesi Fen Bilimleri Enstitüsü Dergisi, 2003, 70-75

${ }^{11}$ G. Çam, Developments in the Tool Used in Friction Stir Welding, TMMOB Chamber of Mechanical Engineers, Welding Technology, IV. National Convention And Exhibition, Kocaeli, 2003, 47-62

${ }^{12} \mathrm{M}$. Boz, A. Kurt, The influence of stirrer geometry on bonding and mechanical properties in friction stir welding process, Materials and Design, 25 (2004) 4, 343-347, doi:10.1016/j.matdes.2003.11.005

${ }^{13}$ K. Kolligan, Material Flow Behavior during Friction Stir Welding of Aluminum, Weld Res. Supply, (1999), 229-237

${ }^{14}$ K. V. Jata, S. L. Semiatin, Continious Dynamic Recristalization During Friction Stir Welding of High Strength Aluminum Alloys, Scripta Materialia, 43 (2000), 743-749, doi:10.1016/s1359-6462(00)00480-2

${ }^{15}$ W. M. Thomas, E. D. Nicholas, Friction stir welding for the transportation industries, Materials and Design, 18 (1997) 4, 269-273, doi:10.1016/s0261-3069(97)00062-9

${ }^{16}$ K. Elangovan, V. Balasubramanian, M. Valliappan, Effect of Tool Pin Profile and Tool Rotational Speed on Mechanical Properties of Friction Stir Welded AA6061 Aluminium Alloy, Materials and Manufacturing Processes, 23 (2008) 3, 251-260, doi:10.1080/ 10426910701860723

${ }^{17}$ H. Fujii, L. Cui, M. Maeda, K. Nogi, Effect of tool shape on mechanical properties and microstructure of friction stir welded aluminum alloys, Materials Science and Engineering A, 419 (2006) 1, 25-31, doi:10.1016/j.msea.2005.11.045

${ }^{18} \mathrm{~S}$. J. Vijay, N. Murugan, Influence of tool pin profile on the metallurgical and mechanical properties of friction stir welded Al-10 wt.\% $\mathrm{TiB}_{2}$ metal matrix composite, Materials and Design, 31 (2010) 7 , 3585-3589, doi:10.1016/j.matdes.2010.01.018 
${ }^{19}$ K. Elangovan, V. Balasubramanian, Influences of tool pin profile and welding speed on the formation of friction stir processing zone in AA2219 aluminium alloy, Journal of Materials Processing Technology, 200 (2008) 1, 163-175, doi:10.1016/j.jmatprotec.2007. 09.019

${ }^{20}$ M. Mehta, A. Arora, A. De, T. Debroy, Tool Geometry for Friction Stir Welding - Optimum Shoulder Diameter, Metallurgical and Materials Transactions A, 42 (2011) 9, 2716-2722, doi:10.1007/ s11661-011-0672-5

${ }^{21} \mathrm{~K}$. Elangovan, V. Balasubramanian, Influences of tool pin profile and tool shoulder diameter on the formation of friction stir processing zone in AA6061 aluminium alloy, Materials and Design, 29 (2008) 2, 362-373, doi:10.1016/j.matdes.2007.01.030

${ }^{22}$ K. Elangovan, V. Balasubramanian, M. Valliappan, Influences of tool pin profile and axial force on the formation of friction stir processing zone in AA6061 aluminium alloy, The International Journal of Advanced Manufacturing Technology, 38 (2011), 285-295, doi:10.1007/s00170-007-1100-2

${ }^{23}$ C. Blignault, D. G. Hattingh, M. N. James, Optimizing Friction Stir Welding via Statistical Design of Tool Geometry and Process Parameters, Journal of Materials Engineering and Performance, 21 (2012) 6, 927-935, doi:10.1007/s11665-011-9984-2

${ }^{24}$ H. Li, D. Mackenzie, R. Hamilton, Parametric finite-element studies on the effect of tool shape in friction stir welding, Proceedings of the Institution of Mechanical Engineers, Part B: Journal of Engineering Manufacture, 224 (2010) B8, 1161-1173, doi:10.1243/ 09544054jem1810

${ }^{25}$ M. Akkurt, Makina Elemanlari Problemleri, Birsen Yayinevi, 1994

${ }^{26}$ B. London, M. Mahoney, B. Bingel, M. Calabrese, D. Waldron, Experimental Methods for Determining Material Flow in Friction Stir Welds, Proceedings of the Third International Symposium on Friction Stir Welding, Kobe, Japan, 2001
${ }^{27}$ C. G. Rhodes, M. W. Mahoney, W. H. Bingel, R. A. Spurling, C. C. Bampton, Effects of FSW on Microstructure of 7075 Aluminum, Scripta Materialia, 36 (1997), 69-75, doi:10.1016/s1359-6462(96) 00344-2

${ }^{28}$ G. Liu, L. E. Murr, C. S. Niou, J. C. McClure, F. R. Vega, Micro Structural Aspects of the Friction Stir Welding of 6061-T6 Aluminum, Scripta Materialia, 37 (1997), 355-361, doi:10.1016/s13596462(97)00093-6

${ }^{29}$ S. Benavides, Y. Li, L. E. Murr, D. Brown, J. C. McClure, Low Temperature Friction Stir Welding of 2024 Aluminum, Scripta Materialia, 41 (1999), 809-815, doi:10.1016/s1359-6462(99) 00226-2

${ }^{30}$ S. Özkan, H. Basak (Supervisor), Sürtünme Karıştırma Kaynağı İle Birleştirilen Parçalarda Haddeleme (Burnishing) İle Yüzeylerin İşlenmesi, Haddelemenin Yüzey Pürüzlülüğü Ve Sertleşmeye Etkisinin İncelenmesi, Gazi Üniveristesi Fen Bilimleri Enstitüsü, Yüksek Lisans Tezi, 2006

${ }^{31}$ H. Basak, S. Ozkan, A. Taskesen, Application of burnishing process on friction stir welding and investigation of the effect of burnishing process on the surface roughness, hardness and strength, Experimental Techniques, 35 (2011) 1, 8-16, doi:10.1111/j.1747-1567. 2009.00555.x

${ }^{32}$ K. Kaptan, H. Basak (Supervisor), Sürtünme karıştırma kaynağı birleştirmelerinde farklı karıştırıcı uç formlarının birleştirme kalitesine etkilerinin incelenmesi, Gazi Üniveristesi Fen Bilimleri Enstitüsü, Yüksek Lisans Tezi, 2009

${ }^{33}$ Turkish Standards Institution, TS 138 EN 10002-1:1996, Metallic materials - Tensile testing, Part 1: Method of test at ambient temperature, 1996 